\title{
A Study on Onychomycosis in Patients Attending Tertiary Care Hospital
}

\author{
Erukulla Anusha ${ }^{1}$, Srinivas $\mathrm{N}^{2 *}$ \\ ${ }^{1}$ Post Graduate, Department of Microbiology, Osmania Medical College, 5-1-876, Turrebaz Khan Rd, Troop Bazaar, Koti, Hyderabad, Telangana \\ 500095, India \\ ${ }^{2}$ Assistant Professor, Department of Microbiology, Osmania Medical College, 5-1-876, Turrebaz Khan Rd, Troop Bazaar, Koti, Hyderabad, Telangana \\ 500095, India
}

DOI: $\underline{10.36348 / \text { sjpm.2020.v05i03.007 }}$ | Received: 22.02 .2020 | Accepted: $04.03 .2020 \mid$ Published: 18.03 .2020

*Corresponding author: Dr. Srinivas N

\section{Abstract}

Etiological agents causing infection in the nails vary with gender, age, occupation, A total number of 51 patients having clinically diagnosed Onychomycosis were selected, Direct microscopy of nail specimen in $40 \% \mathrm{KOH}$, culture on SDA, DTM was done. out of 51 patients, 17 were between 20-30 years of age (33.33\%),out of 51 patients 33 were males and 18 were females, 27 patients $(52.94 \%)$ had DLSO pattern, Of the 32 positive cultures, Dermatophytes were isolated in 10 $(23.80 \%)$ and Non-Dermatophytes in $15(29.41 \%)$. Non-Dermatophyte fungi are being isolated more frequently from nail infections.

Keywords: Onychomycosis, non dermatophytes, SDA, Trichophyton sps, Aspergillus sps.

Copyright @ 2020: This is an open-access article distributed under the terms of the Creative Commons Attribution license which permits unrestricted use, distribution, and reproduction in any medium for non-commercial use (NonCommercial, or CC-BY-NC) provided the original author and sources are credited.

\section{INTRODUCTION}

Onychomycosis is fungal infection of the nail with various etiological agents, viz. dermatophytes, yeasts and non-dermatophyte moulds (NDM), NDM are identified as most common etiological agents in causing nail infection [1-3]. Onychomycosis in immunocompromised patients, can pose a more serious health problem [4]. Not only does the difficult-to-treat infection serve as a constant reminder to the patient of his or her own deteriorated condition, but the possibility exists of transfer of a very high titer of fungal pathogens to another person [4]. The modern health movement and the associated use of occlusive footwear and locker rooms, and migration of people, promoted an increased incidence of onychomycosis [5]. Dermatophytoses of the fingernails and toenails, in contrast to those at other body sites, are particularly difficult to eradicate with drug treatment. This is the consequence of factors intrinsic to the nail-the hard, protective nail plate, sequestration of pathogens between the nail bed and plate, and slow growth of the nail-as well as of the relatively poor efficacy of the early pharmacologic agents This study was done to identify the clinical pattern and isolate the common fungal pathogens responsible for causing onychomycosis so appropriate treatment given.

\section{MATERIALS AND METHODS}

A total number of 280 patients were screened and 51 patients having clinically diagnosed Onychomycosis were selected.Informed consent was taken from them explaining the details in their own language.In all the 51 cases, data related to the age gender, occupation, Nail involvement etc. were noted, COLLECTION OF SPECIMEN: The specimen was collected from the affected portion of the nail bed. Nails were scraped/clipped near the bed, thorough cleansing of the nail area with alcohol to remove contaminants. Using a no. 15 surgical blade, nail plate was removed sufficiently with white debris collected in a sterilized brown paper and kept in sterile labelled container. The specimen was processed on the same day SPECIMEN ANALYSIS: Direct microscopy was done after overnight incubation of the nail specimen in $40 \% \mathrm{KOH}$ for the presence of fungal mycelia and spore, All the nail specimens were washed with absolute alcohol and cultured on, Sabouraud dextrose agar (SDA) with Chloramphenicol,SDA with Chloramphenicol and Cycloheximide, Dermatophyte test medium (DTM). Cultures were incubated at 25 and $37 \mathrm{c}$ for 4 weeks, if any growth detected identified by colony characters and Lactophenol cotton blue preparation, slide cultures done if required. 


\section{RESULTS}

In our study, out of 51 patients, 17 were between 20-30 years of age (33.33\%), 18 were between $31-40$ years of age $(35.29 \%), 14$ were between $41-50$ years of age $(27.45 \%)$ and 2 were between $51-60$ years of age $(3.92 \%)$.Out of the 33 male patients, 24 were manual labourers, 5 were farmers and 2 were vegetable vendors, while 2 were others. Out of 18 female patients, 8 were house wives, 6 were labourers and 4 were dhobis.

Clinical patterns and Nail involvement of Onychomycosis

\begin{tabular}{|c|c|c|c|c|}
\hline $\begin{array}{l}\text { Clinical } \\
\text { pattern }\end{array}$ & $\begin{array}{c}\text { Finger nails } \\
\text { only }\end{array}$ & $\begin{array}{l}\text { Toe nails } \\
\text { only }\end{array}$ & $\begin{array}{l}\text { Both finger } \\
\text { nails and toe } \\
\text { nails }\end{array}$ & Total \\
\hline DLSO & $02(3.92 \%)$ & $23(45.09 \%)$ & $02(3.92 \%)$ & $27(52.94 \%)$ \\
\hline PSO & $01(1.96 \%)$ & $01(1.96 \%)$ & - & $02(3.92 \%)$ \\
\hline WSO & $01(1.96 \%)$ & $06(11.76 \%)$ & $02(3.92 \%)$ & 09 (17.64\%) \\
\hline TDSO & $03(5.88 \%)$ & $02(3.92 \%)$ & $08(15.68 \%)$ & $13(25.49 \%)$ \\
\hline Total & $07(13.72 \%)$ & $32(62.74 \%)$ & $12(23.52 \%)$ & $51(100 \%)$ \\
\hline
\end{tabular}

KOH and Culture positivity of the samples

\begin{tabular}{|l|c|c|}
\hline KOH and Culture results & \multicolumn{1}{|c|}{ Sample } & Percentage \\
\hline Total KOH positive & 33 & 64.70 \\
\hline $\begin{array}{l}\text { Total KOH negative } \\
\text { KOH positive, Culture } \\
\text { negative }\end{array}$ & 18 & 35.29 \\
\hline $\begin{array}{l}\text { Culture positive, } \mathrm{KOH} \\
\text { negative }\end{array}$ & 10 & 21.56 \\
\hline $\begin{array}{l}\text { Both positive } \\
\text { Both negative }\end{array}$ & 22 & 19.60 \\
\hline $\begin{array}{l}\text { Total Culture positive } \\
\text { Total Culture negative }\end{array}$ & 08 & 43.13 \\
\hline
\end{tabular}

\section{Dermatophyte Isolates}

\begin{tabular}{|l|l|}
\hline \multicolumn{1}{|c|}{ Organism } & Total \\
\hline Dermatophytes 10 (23.80\%) & \\
\hline Trichophyton mentagrophytes & $04(9.52 \%)$ \\
\hline T.verrucosum & $02(4.76 \%)$ \\
\hline T.rubrum & $01(2.38 \%)$ \\
\hline Epidermophyton floccosum & $03(7.14 \%)$ \\
\hline
\end{tabular}

Non Dermatophyte Isolates

\begin{tabular}{|l|l|}
\hline Non-dermatophytes 15(29.41\%) & \\
\hline Aspergillus spp. & $04(26.66 \%)$ \\
\hline Epicoccum spp. & $03(20 \%)$ \\
\hline Curvularia & $02(13.33 \%)$ \\
\hline Fusarium & $02(13.33 \%)$ \\
Scopuloriopsis & $02(13.33 \%)$ \\
\hline Trichosporon beigelii & $01(6.66 \%)$ \\
\hline Scytalidium dimidiatum & $01(6.66 \%)$ \\
\hline
\end{tabular}




\begin{tabular}{|l|l|}
\hline \multicolumn{2}{|c|}{ Yeast Isolates } \\
\hline Yeasts $7(\mathbf{1 6 . 6 6 \% )}$ & \\
\hline Candida albicans & $04(9.52 \%)$ \\
\hline Other Candida spp. & $03(7.14 \%)$ \\
\hline No growth $19(37.25 \%)$ & $19(37.25 \%)$ \\
\hline
\end{tabular}

Of the 32 positive cultures, Dermatophytes were isolated in $10(23.80 \%)$ and Non-Dermatophytes in $15(29.41 \%)$. Out of 10 positive dermatophytic cultures; T.mentagrophyte was grown on 04(9.52\%), Epidermophyton floccosum 03 (7.14\%), T.verrucosum $02(4.76 \%)$, T.rubrum $1(2.38 \%)$. Out of the 15 nondermatophytic cultures Aspergillus spp. was isolated on 4(26.66\%), Epicoccum spp. on 3(20\%), Curvularia on $2(13.33 \%)$, Fusarium on 2(13.33\%), Scopuloriopsis on $2(13.33 \%)$, Trichosporon beigelii on 1(6.66\%), Scytalidium dimidiatum on $1(6.66 \%)$. Candida species were isolated on $7(16.66 \%)$. Out of 7 isolates, 4 were C.albicans, 3 were non-albican species.

\section{DISCUSSION}

Most of the men in our study were manual labourers. We found a high incidence of onychomycosis in a age group of 20 to $30 \mathrm{yrs}$ which could be the result of occupation related trauma. Males are more predominant in our study may be due to occupation which is one of the predisposing risk factor. Higher incidence was noted amongst males (33) than females, which compares well with most of the studies [6].

We identified Non dermatophytes, especially Aspergillus spp, to be the most common etiological agents in onychomycosis, and Distal \& Lateral Subungual Onychomycosis to be the common clinical pattern, which has been reported earlier [3]. In the present study Dermatophytes were $23.8 \%$ among this Trichophyton mentagrophytes is the most common which correlates with the study done by Grover et al.,
[7], The high incidence of DLSO pattern has been reported in our study comparable to. Garg et al., [8], In the present study we have come across more cases of fingernail onychomycosis, than toe nail.

\section{CONCLUSION}

Non-Dermatophyte fungi are being isolated more frequently from nail infections. Isolation of the etiological agent is important for proper treatment selection.

\section{REFERENCES}

1. Tosti, A., Piraccini, B. M., \& Lorenzi, S. (2000). Onychomycosis caused by nondermatophytic molds: clinical features and response to treatment of 59 cases. Journal of the American Academy of Dermatology, 42(2), 217-224.

2. Greer, D. L. (1995). Evolving role of nondermatophytes in onychomycosis. International journal of dermatology, 34(8), 521-524.

3. RAMANI, R., Srinivas, C. R., RAMANI, A., KUMARI, T. G. R., \& Shivananda, P. G. (1993). Molds in onychomycosis. International journal of dermatology, 32(12), 877-878.

4. Scher, R. K. (1996). Onychomycosis: a significant medical disorder. Journal of the American Academy of Dermatology, 35(3), S2-S5.

5. Charif, M. A., \& Elewski, B. E. 1997. A historical perspective on onychomycosis. Dermatol Ther, 3:43-45.

6. Sujatha, V., Grover, S., Dash, K., \& Singh, G. (2000). A clinico-mycological evaluation of onychomycosis. Indian Journal of Dermatology, Venereology, and Leprology, 66(5), 238-240

7. Grover, S. (2003). Clinico-mycological evaluation of onychomycosis at Bangalore and Jorhat. Indian Journal of Dermatology, Venereology, and Leprology, 69(4), 284.

8. Garg, A., Venkatesh, V., Singh, M., Pathak, K. P., Kaushal, G. P., \& Agrawal, S. K. (2004). Onychomycosis in central India: a clinicoetiologic correlation. International journal of dermatology, 43(7), 498-502. 